\title{
RUIN PUBS IN BUDAPEST: BLESSING OR CURSE?
}

\author{
István Hajnal, PhD \\ Budapest University of Technology \\ Department of Construction Technology \& Management \\ e-mail:drhajnali@gmail.com
}

\begin{abstract}
One of the most prominent tourist attractions in Budapest is the ruin pub district. Here, in ruined, rundown buildings, clubs that are mainly aimed at young foreigners, participants in party tourism, have sprung up like mushrooms. In Inner Erzsébetváros, the housing prices have significantly risen, since investors see the short- or long-term renting of the apartments as a good opportunity. Those who live in the district, however, find the noise of parties to be too loud, while the crowd and the dirt reduces their quality of life. The apartments located near these pubs are so-called "stigmatized properties", since their value is shaped by the - positive or negative - opinion of the community. Using the method of hedonic analysis, this article examines the question of whether ruin pubs are a blessing or a curse to surrounding apartments, whether their effect increases or, on the contrary, decreases the apartments' values.
\end{abstract}

Key words: Market Value, Blighted Property, Hedonic Pricing Modell, Ruin Pub.

JEL Classification: $R 31, R 320$.

Citation: Hajnal I., 2018, Ruin Pubs in Budapest: Blessing or Curse?, Real Estate Management and Valuation, vol. 26, no. 3, pp. 51-59.

DOI: $10.2478 /$ remav-2018-0024

\section{Introduction}

Budapest has been moving up on various international tourism rankings and lists of the most popular cities. ${ }^{1}$ Many people name the ruin pubs in Budapest as one of the most interesting and exciting attractions. In the central area of Budapest's 7th district, Inner Erzsébetváros, a so-called "ruin pub district" has taken shape over the past decade. The clubs set up in run-down, ruined buildings that attracted local young people were first created out of a lack of funds from investors, but by now, the style has become intentional and emphasized. Instead of further description, here are some photographs that clearly show the type of architectural style that the expression "ruin pub" refers to (Figure 1).

The popularity of ruin pubs is still steadily growing, even though consumers are, in increasing proportions, guests from international party tourism (GÁBOR 2014). The number of ruin pubs is soaring, but their prices are also increasing, and local low-budget consumers are slowly being excluded. The growing number of tourists is certainly favorable for the local economy due to the service providers' income and the taxes paid by them. The phenomenon has significantly boosted real estate trade in the ruin pub district as well (NAGY 2013). Investors involved in peer-to-peer apartment renting (typically through the community network of AirBnB) have appeared and started pushing the prices of the limited supply upwards. According to statistics, the prices of apartments in this area increased by $38 \%$ in the course of three years, i.e. to 2016 (OTP 2017). At the same time, the local residents express their discontent with various activities ${ }^{2}$, since the noise, dirt and crowd have caused the livability of the neighborhood to deteriorate significantly.

${ }^{1}$ http://edition.cnn.com/travel/article/cn-traveler-top-cities/index.html

2 http://nepszava.hu/cikk/1119680-agyo-romkocsmak 


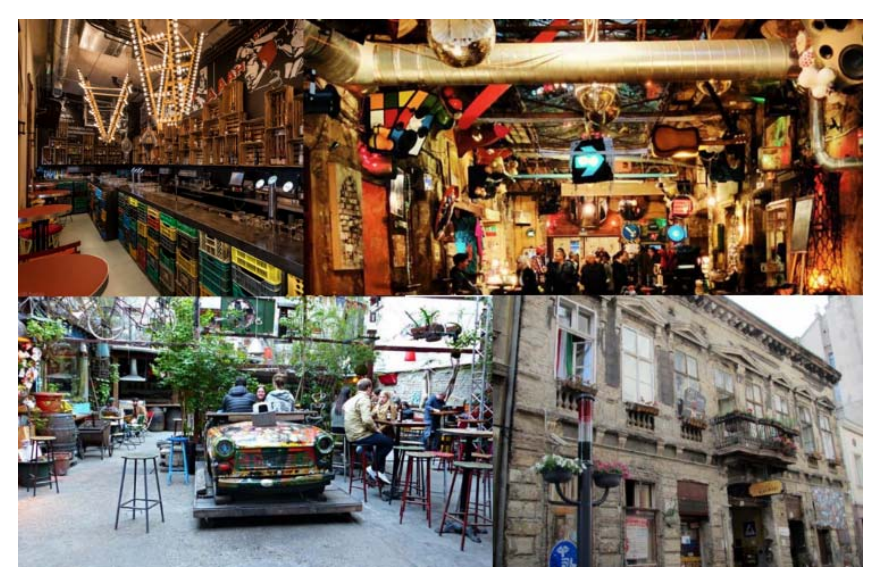

Fig. 1. The architectural moods of ruin pubs. Source: own study.

The international literature has extensively examined the value-changing effect of the environment on real properties for a long time. In situations where the change in value appears through the filters of community and communication, we are dealing with stigmatized properties (HAJNAL 2017). In this study, the author attempts to reveal the value-changing factors of residential properties located near ruin pubs in Budapest as stigmatized properties.

\section{Purpose of the study, hypothesis, limitations}

This study, which relies on limited available real estate market data, examines the value-creating effect of development in a spontaneously evolving district. In order to confirm or disprove various opinions on everyone's lips, possibly even defined as professional, it is logical to set up a model. This is particularly logical, since international literature has researched the effect of environmental effects on the value of properties extensively and in depth, and since, in addition to several other tools, there exists an elaborate model to be used for such examination: the so-called hedonic method. However, it is clear that the database necessary to apply the model is only partially available, and the minimum necessary data content required for carrying out the analysis can also only be generated in an extremely cumbersome manner. Until now, the main obstacle to carrying out such studies in Central Europe has been the lack of data. The transition of the real estate market into electronic space provides an opportunity, albeit a limited one, to attempt to adapt methods and experience of the literature to a Central European example, more specifically, to the ruin pub district in Budapest.

The market value of real estate is shaped by the market players, who take into account the experiences and comparable data gained in previous transactions during each new transaction. The market value is, therefore, not the sum of the physical parameters, but their effect filtered through subjectivity. The noise that bothers the residents of the ruin pub districts can be measured and made objective to some extent, but effects from the existence of the ruin pubs, as well as the environmental noise, appear in the market value of properties through a filter of the community's opinion. With the application of the hedonic model, which will be described later, it can be demonstrated that the effect of noise pollution on the value of real estate does not depend on the actual noise level but on the subjective opinions regarding it (CHASO, GALLO 2012). The subjective perception of the individual, expressed by the Life Satisfaction (LSA) Index, which has been developed for research on environmental pressure (FREY et al. 2009), is a fundamental issue here.

Taking the above points into account, the hypothesis of this study is that real estate market players (sellers, agents, buyers) consider the effect of these catering and entertainment establishments with regard to the housing market prices in the ruin pub district of Budapest as a positive factor. In order to confirm the hypothesis, a hedonic sample area examination is carried out, where the examined area (Inner Erzsébetváros) is the ruin pub district of Budapest in the strictest sense, and the reference sample area (Inner Terézváros) is in the same category from the housing market perspective, except for the fact that it has no ruin pubs.

This research is has its limitations. The study only addresses apartments for sale with regard to the increase in value of properties in the ruin pub district, and only a limited set of them (which will be described later on). Instead of transactional data, the data analysis is based on supply data (obtained 
from advertisements). The analysis, due to the nature of the available data, pertains to a certain moment in time. Changes over time were not analyzed.

\section{Literature review}

\subsection{Application of the hedonic model}

The models applied regarding a decrease in value of stigmatized properties have been systematized by HoRVÁtH et al. (HORVÁtH, HAJNAl 2014), who also made recommendations for their application under various circumstances. Based on this recommendation, the best choice was to apply the hedonic method in the examined situation. The hedonic model was first extended to include application for explaining real estate values in 1970 by KAIN et al.: They grouped 39 variables into 5 categories with factor analysis, examined their regressional relationship, and set up a hedonic formula for calculating housing prices (KAIN, QUIGLEY 1970).

The principle of the hedonic method is the statistical estimation of the relationship between a product's price and attributes. With the model, the value of real estate is broken down into valuecreating elements; each one is assigned a multiplication factor, which expresses the weight of each value-creator in the total value as a "shadow price". The normal linear relationship formula to express the function is the following:

$$
P=\propto+\sum\left(\beta_{i} * x_{i}\right)+\varepsilon
$$

where:

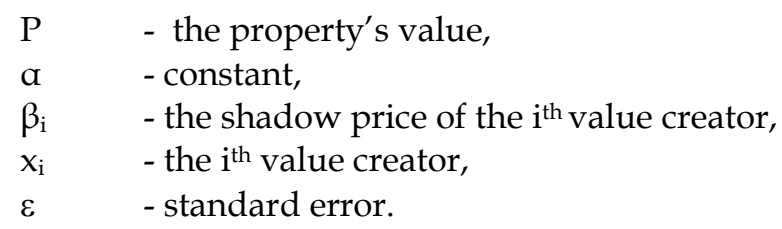

The semi-logarithmic or logarithmic transformation of the variables carried out with the following formula is often applied in order to eliminate the asymmetric development of prices (MALPEZZI, 2008):

$$
\ln P=\propto+\sum\left(\beta_{i} * \ln x_{i}\right)+\varepsilon
$$

One advantage of the hedonic method is that the marginal effect of each value-changing factor can be immediately established based on the results, which also makes cross-referencing real estate evaluation with professional experience easier. The hedonic method is dealt with in extensive literature, dating back nearly half a century. In current international literature, Asian researchers work with the hedonic evaluation method in a particularly thorough manner. Chan et al. found, in their detailed meta-analysis, that the housing market can be described with the attributes of location, building structure and environment. They determined the target value with a logarithmic transformation. In their work, a homogeneous sample of 120 elements shows the functionality of the model well (CHAN, CHIN 2002). Jim et al. also prefers the logarithmic form when examining the value composition of the 600 new apartments in Guangzhou, China (JIM, CHEN 2006). For instance, CHUTI set up a multi-regression model on the value-increasing effect of the metro system in Bangkok, which confirms the hypothesis in certain areas (i.e. a nearby metro line increases the value of the real estate) very well (CHUTI 2011). A hedonic analysis has been carried out on almost every environmental attribute; in 2003, Chau had already carried out the meta-analysis of 85 such studies (CHAU et al. 2003). The analysis of hedonic models regarding environmental variables can be called a sort of "success story", since the results of such research are usually indispensable for decision makers (PALMQUIST, SMITH 2002)

\subsection{Value-changing effect of environmental variables}

In a summary, Bell described the modelling procedures for the problem of the value-changing effect exerted by environmental variables, as well as the findings made with regard to them (BELL 2001). The author categorized the possible methods into two groups: HP (Hedonic Pricing) and SP (Stated Preference). The non-traditional methods have subsequently improved a lot; in addition to HP, new approaches based on artificial intelligence (AI), including artificial neural networks (ANN) (ABIDOYE, CHAN 2016) and Fuzzy Logic (LiU et al. 2006) have also emerged. Another new approach in evaluation 


\section{S sciendo}

is the application of stock market option theory (RENIGIER-BIŁOZOR, D'AMATO 2017). Welfare economics analyzes the effect of environmental characteristics on non-market value in detail, using the main method of measuring Willingness to Pay (WTP) (HAAB, MCCONNELL 2002).

Researchers have examined issues similar to the matter raised in this study using the hedonic method. HAJNAL (2012) examined the value-reducing capacity of telecommunication towers with a hedonic method. MORANCHO also used a hedonic model in Barcelona, and found that only the distance of green parks appears in the transaction price model of environmental effects, regardless of the park's size (MORANCHO 2003). Several analyses have examined the value-reducing effect of airport noise, confirming the general finding that a 1-Db increase in noise pollution generally leads to a $1 \%$ decrease in real estate value (BELL 2001; NELSON 2008; LAZIC, GOLASZEWSKI 2006; BOES, NÜESCH 2010). In England, GiBBONS et al. examined the added value of natural characteristics of the environment by regions (GIBBONS et al. 2011). Some researchers have set refining the hedonic variables as an objective. For instance, HERATH found that the generally applied factor of "having a bus stop within 400 meters" as a value-increasing agent does not result in a significant change (in the examined sample from Sydney), though it can be clearly seen that the attribute of "having a bus stop within 200 meters" increases the value of real estates by $6.8 \%$ (HERATH 2015).

In general, research on the value-reducing effect of environmental factors is not yet extensive, which is primarily due to the lack of data. SZCZEPAŃSKA et al. examined the effect of parks on real estate prices in Poland (SZCZEPAŃSKA et al. 2016). In Hungary, the introduction of non-traditional evaluation models is still in its early stage; the examination of introducing these types of models, usually called AVMs (Automated Valuation Model), is still in progress (HORVÁtH et al. 2016). Some research has already been carried out on using the hedonic model on the housing market in Budapest (HORVÁTH, SZÉKELY 2007; KUTASI, BADICS 2016), as well as on detecting the stigmatizing effect of the Budapest Ferenc Liszt International Airport (HAJNAL 2017) and the differences in the values of historical buildings (KUTASI 2016).

\section{Data and methods}

Residential properties in two areas of Budapest of a very similar nature were selected for the hedonic examination. In the sample area process, we assume that values in the two areas are similar, and the difference between them is only caused by the fact that in one of the areas ruin pubs are widespread, while in the other area - they are few and far between. The map in Figure 2 shows the location of major ruin pubs in Budapest.

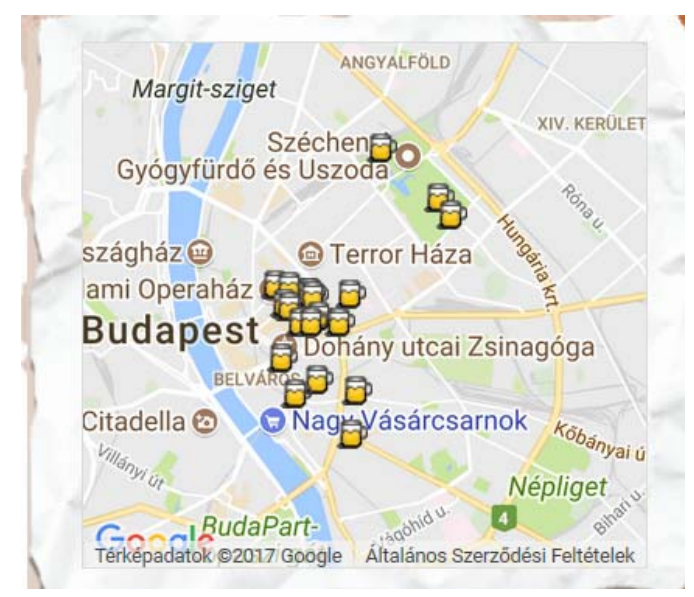

Fig. 2: Locations of ruin pubs in Budapest (source: www.romkocsma.hu). Source: own study.

Examining the environment of ruin pubs, we can see that the location of these areas within the city, their traffic conditions and other urbanistic characteristics are similar. The area outside of the city walls of Pest started to urbanize in the beginning of the 19th century, when the current street system evolved and their development was carried out. The current form of the street network took its present shape after the establishment of Andrássy Avenue and Grand Boulevard in the 1870s. The history of the two areas is closely intertwined, since Erzsébetváros did not secede from Terézváros 
until 1882. The effective Integrated Urban Development Strategy ${ }^{3}$ refers to Inner Terézváros as the "Broadway in Pest", where, in addition to high-quality dwellings, the function of cultural establishment is also dominant. Inner Erzsébetváros is known in colloquial architectural language as the "Jewish Quarter", since the Pest ghetto was set up here in 1944. The composition of the residents is homogeneous and shows an aging and decreasing tendency. However, the city center in Pest, including both of the examined areas, in the surroundings of Andrássy Avenue (which is part of the World Heritage), is a tourism destination area in Budapest and, therefore, the number of accommodation establishments is continuously increasing. Access is very good to both areas, but the unresolved issue of parking equally reduces comfort in the two regions. The buildings are old, both in the examined area and the reference area (86\% were built before 1945), and renovations have been foregone, with regard to individual apartments as well as common building structures. There are several buildings in the examined area that obtained the status of "historical monument", and these monuments and protected buildings, built mostly in eclectic, art nouveau and classicist style, represent outstanding architectural value. Thus, we can conclude that, based on data on the city's structure, the buildings' architecture and the land use, our previous assumption that the housing market characteristics of the two areas are similar is correct.

The housing markets of the two areas have significantly improved after the global crisis; prices have been continuously growing over the past five years. Using the sample from the raw database, it can be clearly seen on Graph 3 that the development is persistent in Inner Erzsébetváros, and that the prices there first exceeded those in Inner Terézváros in 2016. In the case of the later, the slowing down of price increases in Budapest is already being felt. The graph presented here seems to support the hypothesis of this study: party tourism has a value-increasing effect on the housing market prices of the ruin pub district.

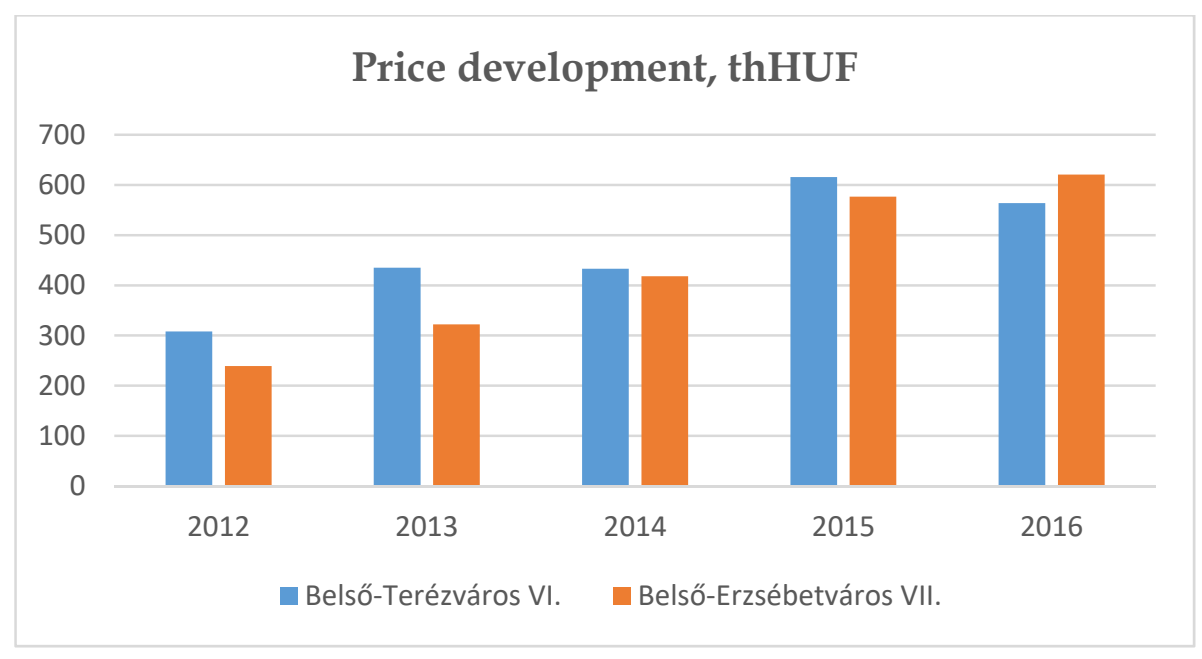

Fig. 3: Changes in prices in the two examined environments (source: www.ingatlan.com). Source: own study.

No public database that contains the significant parameters of properties necessary for a market evaluation is available in Hungary. The problem with the public database of duties maintained by the National Tax and Customs Administration is that it does not contain the data necessary for the examination (the condition of the apartments, number of rooms, comfort level). Therefore, we chose the advertisement database as a source of core data. A significant proportion of the current real estate supply in Hungary can be found on the "ingatlan.com" website. According to the statement made by the company that operates the website (Arkon Zrt.), the portal is a market leader and the vast majority of the supply can be found on it $\mathrm{t}^{4}$ t this statement is confirmed by the experiences of housing companies as well. With regard to the relationship between offer prices and real transaction prices, we can conclude, based on a study carried out by OTP, that there is a strong correlation between the two data

\footnotetext{
3 http:/ / www.terezvaros.hu/index.php?section=modules/content/content_pages.php\&content_ pages_id=264, downloaded on 23 October 2017.

4 "Development according to Demand" ("Fejlesztés az igények szerint.") http://info.ingatlan.com/ downloaded on $16 / 10 / 2015$.
} 


\section{S sciendo}

sets, and this relation is continuously growing stronger - offer prices are approaching the level of actual transaction prices (OTP, 2017). In view of the above, we have found the database of "ingatlan.com" to be suitable for this research - with the corrections and notes explained later on. The samples are from the same date, 21 September 2017.

We collected relevant data for the two examined areas by setting a filter for a surface area between 45 and 95 square meters. We selected "apartments for sale", a category which contains condominiums, as a filtering option. The raw sample of duplicates were scoured by selecting from several offers for the same real estate the data from the most current advertisement (which specifies the current supply). We also purged the sample of outliers and evidently faulty data. The test sample therefore contains 58 items for Inner Erzsébetváros and 85 items for Inner Terézváros.

We collected the following data from the advertisement database for each property (record): offer price, flat area, number of rooms, type of heating and street (road) name. The greatest flaw in the examined database is that it does not enable spatial analysis, since only a quarter of its advertisements contain spatial descriptive data (street name with exact number), but based on the agents' experience, even this information is often misleading or incorrect. However, the advertisement database contained a lot of data on the condition of the property, including descriptions and photos, with a different quantity of data for each record. We analyzed and weighed these data separately for each property, and eventually summarized them in a single "condition" variable. This "condition" variable therefore includes the following characteristics: date of construction, structure, coverings, renovation, architectural value. We graded this variable on a scale of 0 to 5 ( 0 being the worst condition and requiring complete renovation, 5 being the best property with outstanding technical properties, practically in newly-built condition).

Some typical statistical values from the database (separated for the two areas) are shown in the following table (Table 1).

Table 1

Typical statistical data in the sample

\begin{tabular}{lccc}
\hline & Terézváros & Erzsébetváros & Together \\
\hline Number of items in the cleaned sample & 85 & 58 & 143 \\
\hline Average surface area (m2) & 67.44 & 71.52 & 69.09 \\
\hline Average condition & 3.16 & 3.58 & 3.38 \\
\hline Average offer price (mHUF) & 52.18 & 46.90 & 50.04 \\
\hline Average specific offer price (thHUF/m2) & 772.65 & 669.50 & 730.81 \\
\hline Minimum specific offer price (thHUF/m2) & 303.28 & 324.47 & 303.28 \\
\hline Maximum specific offer price (thHUF/m2) & 2386.88 & 1153.33 & 2386.88 \\
\hline $\begin{array}{l}\text { Standard deviation of the specific offer } \\
\text { price (thHUF/m2) }\end{array}$ & 285.11 & 162.79 & 249.13 \\
\hline
\end{tabular}

Source: own study.

In the table, the specific price was calculated in accordance with the norm in the housing market, for the floor space of the apartment. Unlike the complete statistics that contain generalized data, the detailed comparison between the cleaned, specific square meter data for the two areas contradicts the hypothesis that the prices in Inner Erzsébetváros, the ruin pub district, are higher.

\section{Empirical results}

We examined the variables in the database described above with a linear regression analysis based on the hedonic model ${ }^{5}$. Logically, we selected offer price (AskPrice) as a dependent variable, which we also considered to be an approximation of the market value of the individual property. The independent variables first examined were as follows:

- surface area of the apartment $\left(\mathrm{m}^{2}\right)-S Q M$,

- number of rooms in the apartment (pc) - NoRoom,

- heating system in the apartment - Heating,

- condition of the apartment - TechStatus,

5 The calculations were made using SPSS version 24. 
- location - dummy variable; its value is 1 if the location is in Terézváros and 0 if it is in Erzsébetváros (the "party district") - Loc.

We made the calculations in the hedonic model using the offer prices of the apartments. We categorized heating systems into 4 groups based on how modern they were: Group 1 was the worst (gas heater) and Group 4 was the most modern (central heating) category. As we had already mentioned, the condition of each apartment was measured on a scale of 0 to 5 . The location dummy variable took on the value of 0 for Inner Erzsébetváros and 1 for Inner Terézváros.

We examined the relationship with direct, semi-log and log-log forms, and found that the logarithmic relation had the highest explanatory power (without transformation, $\mathrm{R}^{2}=0.497$; using the natural logarithm of the offer price in semi-log relation, $\mathrm{R}^{2}=0.549$; while writing dependent and independent variables in a natural logarithm, $\mathrm{R}^{2}=0.550$ ). Relations of similar international and local examinations usually show the explanatory power of the model to be between 50-70\%, therefore, we concluded that our established model fits among similar analyses. In order to ensure easier management in the course of further analyses, we used the semi-log model, which has the same explanatory power as the log-log model does.

We used the so-called "stepwise" process to filter out the determining variables. After running the model, it became clear that the floor area, the type of heating and the condition variables are determining, while the number of rooms is not. Therefore, we subsequently disregarded this variable. Whether the property is in the "party district" or Inner Terézváros, which was selected as the sample area, is also significant. Based on the hedonic model's decomposition, prices on the housing market of the sample area are significantly higher than those in the ruin pub district (Table 2).

Table 2

Data of running the semi-log model

\begin{tabular}{|c|c|c|c|c|c|c|}
\hline \multicolumn{7}{|c|}{ Coefficients $^{a}$} \\
\hline & & \multicolumn{5}{|c|}{ Standardized } \\
\hline & & Unstandardize & Coefficients & Coefficients & & \\
\hline \multicolumn{2}{|c|}{ Model } & B & Std. Error & Beta & $\mathrm{t}$ & Sig. \\
\hline \multirow[t]{5}{*}{1} & (Constant) & 2.547 & .109 & & 23.358 & .000 \\
\hline & SQM & .012 & .001 & .538 & 9.269 & .000 \\
\hline & Heating & .053 & .019 & .184 & 2.886 & .005 \\
\hline & TechStatus & .078 & .012 & .413 & 6.435 & 000 \\
\hline & Loc & .123 & .038 & .189 & 3.218 & 002 \\
\hline
\end{tabular}

a. Dependent Variable: LnAskPrice

Note: $n=141 ; R^{2}=0,549$

Source: own study.

In the examined sample arean - Inner Terézváros -there are several key main roads, such Andrássy Avenue and Bajcsy-Zsilinszky Street. We examined how the model changes if we remove properties located along these from the sample (Table 3).

Table 3

Most important data of the model without main roads

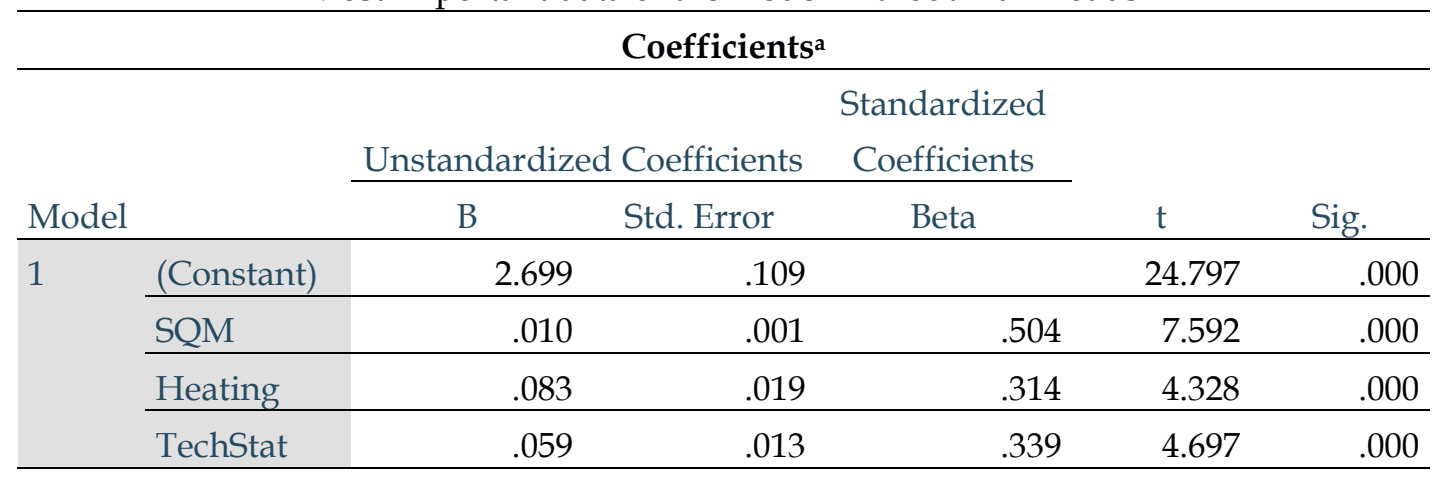




\begin{tabular}{cccccr}
\hline Loc & .068 & .039 & .117 & 1.733 & .086 \\
\hline a. Dependent Variable: InAskPrice & & & & & \\
\hline Note: $n=108 ; R^{2}=0,569$ & & Source: own study.
\end{tabular}

It is clear that the explanatory power of the model did not significantly increase due to this modification $\left(R^{2}=0.569\right)$, however, the extent of appreciation caused by location significantly decreased.

\section{Discussion and conclusions}

Applying the results on an average property, we found that, in Inner Terézváros, which was used as a sample area, housing prices are significantly higher, and the added value of the "location" is $11.8 \%$. If we disregard the effect of key main roads, the additional value is only $3.3 \%$.

Based on the examination of the model described above, we can definitely draw the conclusion that the increase in value of apartments in the ruin pub district, which is prominent in popular belief, does not in fact exist. By decomposing the offer prices, we found that the value of "location" is higher in Inner Terézváros than in Inner Erzsébetváros. Therefore, the hypothesis described in the introduction must be rejected; the increase in value in the ruin pub district cannot be confirmed. On the contrary: due to the community's opinion on noise, dirt and crowd, prices are below those in the sample area of similar characteristics.

For further analysis, data on the individual properties' locations and their spatial information, as well as their analysis, is required. This could help in determining, with the help of spatial analysis of the ruin pubs' immediate neighborhood, whether the general tendencies observed here change with increasing distance from individual clubs. In order to determine how the community's opinion shows in prices over time, as well as take into account and filter out the effects of market changes, we will need to rely on data from longer time series. Obtaining and evaluating these data can significantly refine the initial results of this analysis.

\section{References}

AbIDOYe R. B., CHAN, A., 2016, Review of ANN Application in Property Valuation, Proc. of the 33rd CIB W78 Conference 2016, Oct. 31st - Nov. 2nd 2016, Brisbane, Australia.

BeLL R., 2001,The Impact of Airport Noise on Residential Real Estate, The Appraisal Journal, July 2001. pp 312-321.

BOES S., NÜESCH, S., 2010, Quasi-experimental Evidence on the Effect of Aircraft Noise on Apartment Rents, Journal of Urban Economics (2010), doi:10.1016/j.jue.2010.09.007.

ChAn K. W., CHIN T. L., 2002, A Critical Review of Literature on the Hedonic Price Model and Its Application to the Housing Market in Penang, The seventh Asian Real Estate Society Conference, pp 12, Seul.

CHASO C., GAllo J., 2012, The Impact of Objective and Subjective Measures of Air Quality and Noise on House Prices: A Multilevel Approach for Downtown Madrid, Economic Geography, Clark University, vol. 89(2), pp. 127-148.

CHAU K. W., YIU C. Y., WONG S. K., LAI L.W.C., 2003, Hedonic Price Modelling of Environmental Attributes: a Review of the Liiterature and a Hong Kong Case Study, Understanding and implementing sustainable development, 87-110.

CHUTI T., 2011, The Influence of Rapid Transit Systems on Condominium Prices in Bangkok, Master Thesis, KTH University, Stockholm.

FREY B., S., LUECHINGER S., STUTZER A., 2009, The Life Satisfaction Approach to Environmental Valuation, CESifo working paper, No. 2836, http://hdl.handle.net/10419/30462, accessed 2015. 10. 23.

GÁBOR D. G., 2015, "Underground Hospitality” - Ruin-Pubs: The New Attractions of Budapest, E-Conom, 2014 III/1; DOI: 10.17836/EC.2014.1.107.

Gibbons S., Mourato S., Resende G., 2011, The Amenity Value of English Nature: a Hedonic Price Approach, SERC Discussion Papers, SERCDP0074. Spatial Economics Research Centre (SERC), London School of Economics and Political Sciences, London, UK.

HAAB T. C., MCCONNELl K. E., 2002, Valuing Environmental and Natural Resources: The Econometrics of Non-Market Valuation, Edward Elgar Publishing, ISBN 1840647043.

HAJNAL I., 2012, Mobil-adótornyok értékcsökkentő hatása (Stigmatizing Effects of Mobile Phone Transmission Towers), MAGYAR ÉPÍTŐIPAR 3, 62 évf. pp. 86-91. 
HajNal I., 2017, An Investigation of Property Value Impairment Caused by Noise, in the Case of the Budapest Ferenc Liszt International Airport, Using a Hedonic Model, Periodica Polytechnica-Social And Management Sciences 25:(1) pp. 49-55.

HajNAL I., 2017, Stigmatised Property: A Method of Comparing Blights, Procedia Engineering 196: pp. 375382.

Herath S., 2015, How Far is too Far from Public Transport? An Empirical Assesment, RICS COBRA AUBEA 2015 Conference Proceedings, Sydney, ISBN: 978-1-78321-071-8

HORVÁTH Á., IMRE B., SÁPI Z., 2016, Ingatlanok statisztikai értékmeghatározásának nemzetközi gyakorlata, az automatizált értékelési modellek bevezetésének hazai lehetôségei, (International Practice of Statistical Valuation Methods for Real Estate, Potential Hungarian Usage of AVM models), Discussion Papers, MT-DP - 2016/34, MTA KÖZGAZDASÁG - ÉS REGIONÁLIS TUDOMÁNYI KUTATÓKÖZPONT KÖZGAZDASÁG-TUDOMÁNYI INTÉZET - BUDAPEST.

HoRvÁTH Á., SzÉKELY G., 2007, Hedonikus módszerek alkalmazása a használt lakások áralakulásának megfigyelésében; Statisztikai Szemle, 87 évfolyam 6. szám; pp 595-607.

HorvÁTH K., HAJNAL I., 2014, Value Impairment of Contaminated Real Estate, Periodica Polytechnica Social and Management Sciences, Vol. 22, No. 2, pp. 141-148, 2014. DOI: 10.3311/PPso.7389.

JIM C.Y., CHEN W. Y., 2006, Impacts of Urban Environmental Elements on Residential Housing Prices in Guangzhou (China), Landscape and Urban Planning 78 (2006) 422-434; DOI: 10.1016/j.landurbplan.2005.12.003.

KaIN J. F., Quigley J. M., 1970, Measuring the Value of Housing Quality, Journal of the American Statistical Association. 65. évf. 330. pp. 532-548.

KUTASI D., BADICS M. Cs., 2016, Valuation Methods for the Housing Market: Evidence from Budapest, Acta Oeconomica,Vol. 66 (3), pp. 529-548 (2016) DOI: 10.1556/032.2016.66.3.8.

KUTASI D., 2016, Value Components of Historic Residential Properties: Evidence from Budapest Real Estate Market, Open House International 41:(1) pp. 101-106.

Lazic A., GolaszewsKi R., 2006, A Technical Note on Aircraft Noise and its Cost to Society, GRA, Incorporated, Corporate White Paper.

LiU J.-G., ZhANG X.-L., WU W.-P., 2006, Application of Fuzzy Neural Network for Real estate Prediction, in J. Wang, Z. Yi, J. M. Zurada, B.-L. Lu and H. Yin Ed. Advances in Neural Networks-ISNN 2006, Springer, Berlin Heidelberg, pp. 1187-1191.

MALPeZZI S., 2008, Hedonic Pricing Models: a Selective and Applied Reiew, in: O'Sullivan, T., Gibb, K. (Eds.), Housing Economics and Public Policy, Blackwell Science, Oxford, pp. 67-89.

MoRANCHO A. B., 2003, A Hedonic Valuation of Urban Green Areas, Landscape and Urban Planning, pp. 35-41, DOI: 10.1016/S0169-2046(03)00093-8.

NAGY B., 2013, Romkocsma mellett laksz? - Többet érhet a lakásod, (Living Nearby a Ruin-bar: Your Flat worth Mre) Portfolio.hu, http://www.portfolio.hu/ingatlan/l/akas/romkocsma-mellett-laksztobbet-erhet-a-/lakasod.181502.html, accessed at 2017.10.17.

NeLSON J.P., 2008, Hedonic Property Value Studies of Transportation Noise: Aircraft and Road Traffic, in: Baranzini, A. Ramirez, J., Schaerer, C. (Ed) "Hedonic Methods in Housing Markets, Pricing Environmental Amenities and Segregation" ISBN: 978-0-387-76814-4, Springer.

OTP Lakóingatlan Értéktérkép 2017/1 https:/ / www.otpbank.hu/OTP_JZB/file/.

OTP_Lakoingatlan_Ertekterkep_2017_1.pdf, accessed at 2017.10.16.

PalmQuist R. B., V. K. SMith 2002, The Use of Hedonic Property Value Techniques for Policy and Litigation, In The International Yearbook of Environmental and Resource Economics 2002/2003, T. Tietenberg and H. Folmer, eds., Elgar: Cheltenham, UK, 115-64.

Renigier-BiŁozor M., D'AMATo M., 2017, The Valuation of Hope Value for Real Estate Development, Real Estate Management and Valuation, vol. 25, No. 2, pp. 91-101.

SZCZEPAŃSKA A., KRZYWNICKA I., LEMAŃSKI L., 2016, Urban Greenery as a Component of Real Estate Value, Real Estate Management and Valuation, vol. 24, No. 4, pp. 79-87. 